\title{
Role of smoke-free legislation on emergency department admissions for smoking-related diseases in Kocaeli, Turkey
}

\author{
F. Yıldız, ${ }^{1}$ S.A. Barıš, ${ }^{1}$ i. Başyiğit, ${ }^{1}$ H. Boyacı, ${ }^{1}$ H. Aydınlık² and P.Ö. Sönmez ${ }^{2}$
}

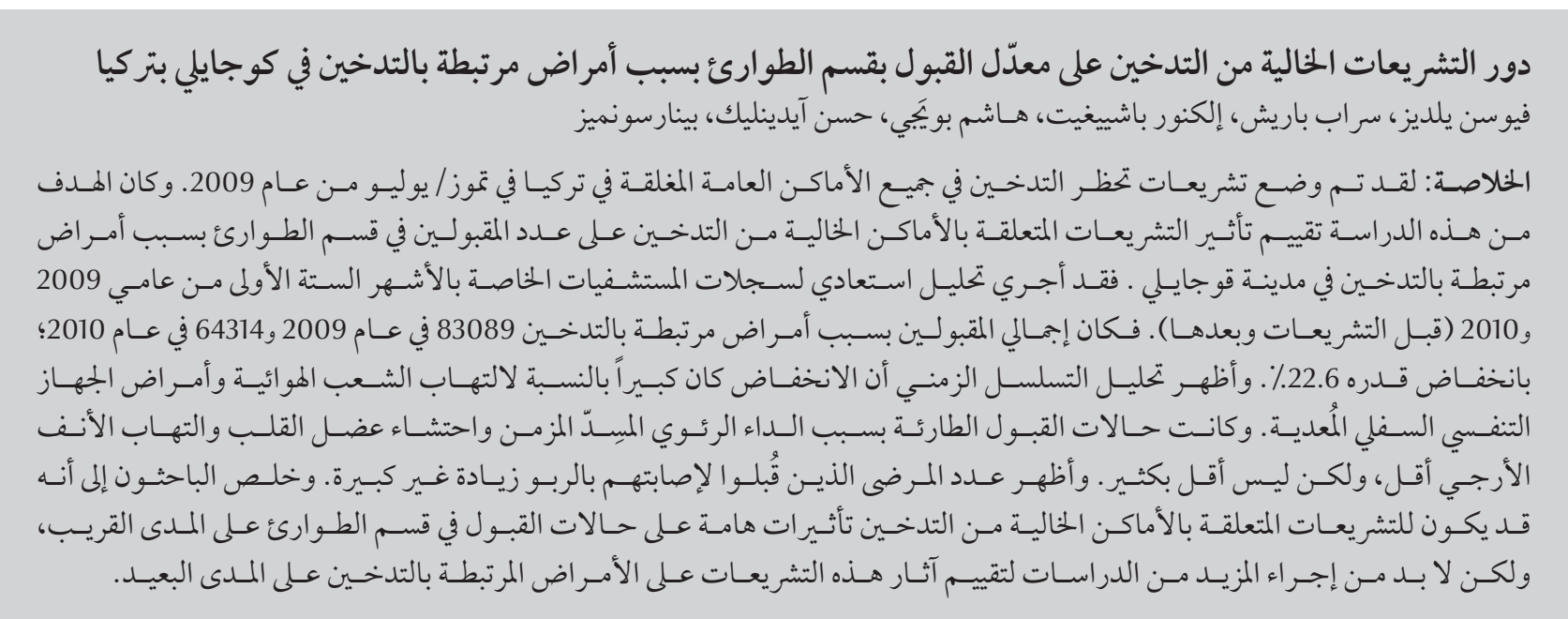

ABSTRACT Legislation banning smoking in all indoor public places was introduced in Turkey in July 2009. The aim of this study was to evaluate the role of smoke-free legislation on the number of emergency department admissions for smoking-related diseases in Kocaeli city. A retrospective analysis was made of hospital records from the first 6 months of 2009 and 2010 (before and after legislation). Total admissions for smoking-related diseases were 83089 in 2009 and 64314 in 2010, a 22.6\% decrease. Time-series analysis showed that the decreases were significant for bronchitis and lower respiratory tract infections. Emergency admissions for chronic obstructive pulmonary disease, myocardial infarction and allergic rhinitis were lower but not significantly so. The number of patients admitted with asthma showed a non-significant increase. Smoke-free legislation might have important short-term effects on emergency department admissions, but further studies are needed in order to evaluate the long-term effects of legislation on smoking-related diseases.

Effets d'une législation antitabac sur le nombre de patients admis au service des urgences pour des maladies liées au tabagisme à Kocaeli (Turquie)

RÉSUMÉ La législation sur l'interdiction de fumer dans tous les lieux publics intérieurs a été adoptée en Turquie en 2009. L'objectif de la présente étude était d'évaluer les effets de la législation antitabac sur le nombre de patients admisauxurgencespourdesmaladiesliéesautabagismedanslavilledeKocaeli.Uneanalyserétrospectivedesdossiers hospitaliers a été réalisée, et celle-ci portait sur les six premiers mois de 2009 (avant l'adoption de la législation ) ainsi que sur les six premiers mois de 2010 (après l'adoption de la législation). Le nombre total d'hospitalisations pour des maladies liées au tabagisme était de 83089 en 2009 et de 64314 en 2010, représentant une baisse de 22,6\%. L'analyse des séries chronologiques a démontré que les diminutions étaient importantes pour la bronchite et les infections des voies respiratoires inférieures. Le nombre d'hospitalisations en urgence pour la bronchopneumopathie chronique obstructive, l'infarctus du myocarde et la rhinite allergique était inférieur mais la baisse n'était pas significative. Le nombre de patients asthmatiques hospitalisés a augmenté de manière non significative. Une législation antitabac peut produire d'importants effets à court terme sur le nombre d'hospitalisations au service des urgences, mais des études supplémentaires sont requises afin d'évaluer les effets à long terme de la législation sur les maladies liées au tabagisme. 


\section{Introduction}

Tobacco use is the leading cause of preventable disease and death worldwide (1). Certain health problems can be attributed to both active and second-hand smoke. Second-hand smoke is defined as involuntary exposure to a combination of diluted, side-stream cigarette smoke and exhaled smoke from smokers (2). There is increasing evidence that passive smoking is an important risk factor for chronic respiratory diseases. A number of studies suggest that asthma can be induced by exposure to passive smoking, and there is strong evidence to suggest that passive smoking increases the risk of general respiratory symptoms (3-6). In recent years, the mounting evidence available on the adverse effects of second-hand smoke has prompted several countries to introduce smoking bans in indoor public places. Turkey is one such country, and legislation banning smoking in all indoor public places, including cafes and restaurants, was introduced on 19 July 2009.

A number of studies have investigated the impact of smoke-free legislation and have reported a reduction in the rate of hospital admissions for acute cardiovascular diseases in the general population after enforcement of smoking bans in indoor public places. There is still uncertainty, however, about the magnitude of this reduction, with estimates ranging from $0 \%$ to $70 \%(7-12)$. Few studies have examined the impact of smoking legislation on respiratory outcomes (13-17).

The aim of the study was to evaluate admissions to emergency departments for smoking-related diseases prior to and following the introduction of smoke-free legislation in Kocaeli city in the north-west of Turkey.

\section{Methods}

\section{Study design and setting}

The number of patients visiting emergency departments with a smoking-related disease was evaluated retrospectively over 6-month periods before and after the implementation of smoke-free legislation on 19 July 2009. Data obtained for the period January to June 2009 were compared with data from January to June 2010. Emergency department admission records were examined in 13 hospitals in the city. Kocaeli city consists of 12 districts, 7 of which contain 1 or 2 state hospitals (total 10 state hospitals). We included all state hospitals, including Kocaeli University Hospital, and 3 private hospitals located in Kocaeli city centre.

\section{Diseases recorded}

We collected data on asthma, chronic obstructive pulmonary disease (COPD) and myocardial infarction because previous studies investigating the effects of smoking bans on emergency admissions have generally included these. We also extended the spectrum of diseases to investigate nasopharyngitis, rhinitis, bronchitis and lower respiratory tract infections (LRTIs). We hypothesized that, although the evidence of a relationship of these other respiratory conditions with tobacco consumption has not been clearly determined, smoking might have an important role in aggravation of these diseases. We therefore recorded admissions diagnosed under the International Classification of Diseases (ICD) codes for bronchitis (J.20), LRTI/pneumonia (J.22/J.18), allergic rhinitis (J.30), asthma (J.45), COPD (J.44) and myocardial infarction (I.21).

\section{Statistical methods}

We tested the hypothesis that the implementation of the anti-smoking law was associated with changes in the total number of emergency department admissions for smoking-related diseases in the 6 months from January to June. We compared the number of admissions during the 6 months after the law had come into effect (2010) with the average number of admissions during the same 6 months in the year prior to the law being passed (2009). Also the time-series design and analysis of the slopes of the 2 trendlines were performed for each disease. The forecasting equation for the linear trend model was: $Y(t)=a$ $+\beta(t)$, where $t$ is the time index. The parameters $\alpha$ and $\beta$ (the intercept and slope of the trendline) are usually estimated via a simple regression in which $Y$ is the dependent variable and the time index $t$ is the independent variable. The trend analysis was performed for both years. Student t-test was used to compare the slopes of the 2 trendlines. A $P$-value $<0.05$ was considered statistically significant.

\section{Results}

The total number of emergency department admissions for smoking-related diseases was 83089 over the period January-June 2009 and 64314 over January-June 2010. This represented a total reduction of $22.6 \%$ (Figure 1). There was a progressive decrease in the monthly number of emergency department admissions for smokingrelated diseases between January and June 2009 and this continued to fall over January to June 2010 after smokefree legislation (Figure 2).

The annual numbers of emergency department admissions for the different smoking-related diseases before and after the smoke-free legislation are shown in Figure 1. The decrease was most marked for bronchitis. The number of patients who were admitted to the emergency department with the diagnosis of chronic bronchitis was 44141 for the 6-month period in 2009 and this number decreased to 26558 over the same 6-month period in 2010, a reduction of $39.8 \%$. Comparisons of the slopes of the 2 trendlines of each disease are shown in Table 1 . There was a statistically significant decrease in admissions for 


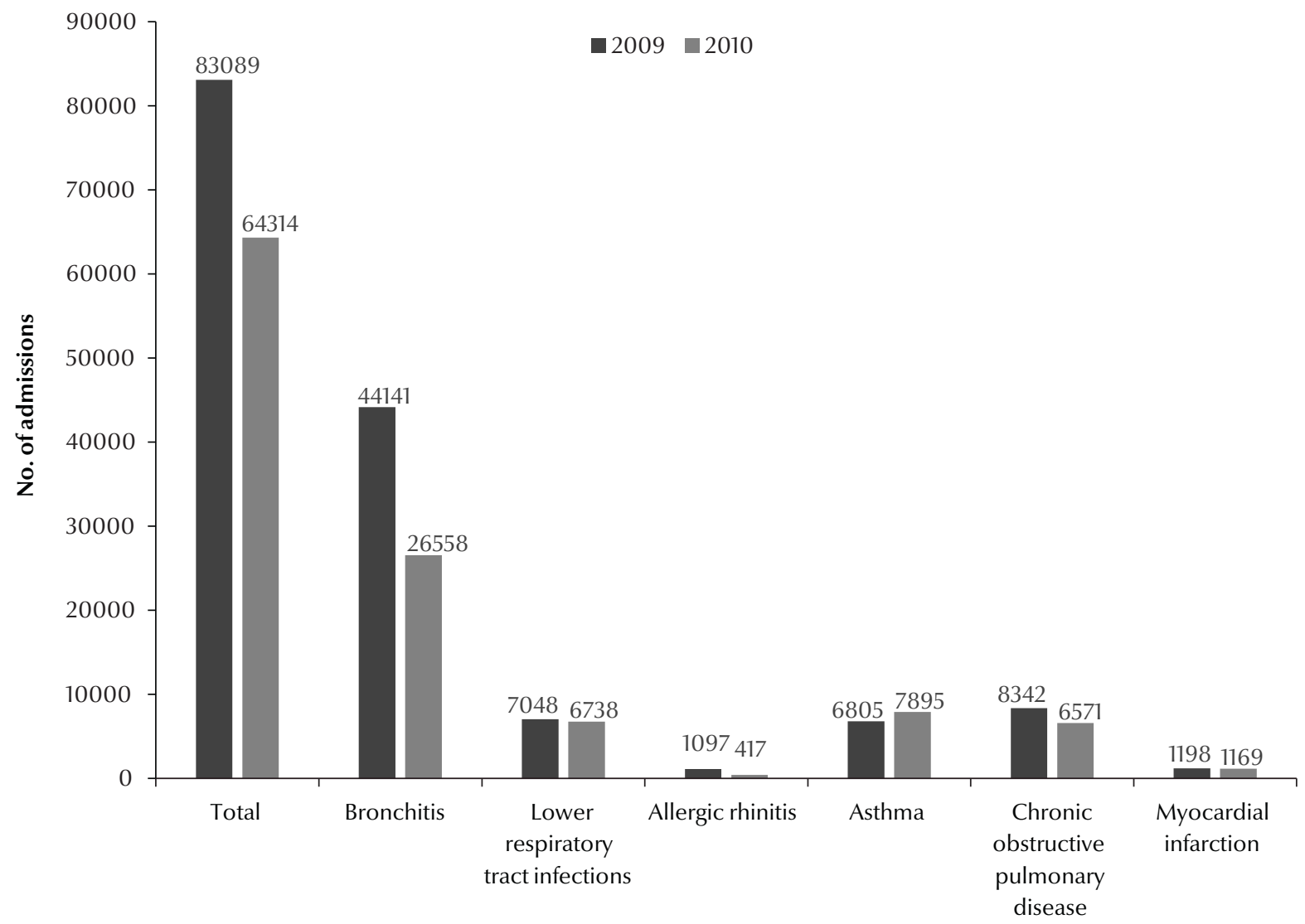

Figure 1 Annual number of emergency department admissions for the different smoking-related diseases before and after smoke-free legislation

bronchitis according to time-series analysis $(P<0.05)$ (Figure 3$)$.

There was also a significant difference in the number of admissions for LRTIs after the legislation (Figure 1) and the trend analysis showed that this was significant $(P<0.01)$ (Table 1$)$ (Figure 4). Although the monthly trend analysis showed a sharp peak in LRTIs in May, the decrease in admissions in the first 4 months of 2010 may be responsible for the significant results in trend analysis.

There was a large decrease in the numbers of patients admitted to emergency departments with COPD after the smoking legislation was introduced than before (8342 versus 6571) and a smaller decrease in admissions for myocardial infarction (1198 versus 1169) (Figure 1). These decreases, however, were not statistically significant for
COPD (Figure 5) or for myocardial infarction according to the trend analysis results $(P>0.05)$ (Table 1$)$.

Admissions for allergic rhinitis decreased from 1097 to 417 (Figure 1). There was a $61.9 \%$ reduction in emergency admissions for allergic rhinitis in the first 6 months of 2009 and 2010 and although there was a peak in April in 2009 this peak was not observed in 2010. According to the 2 trend analysis

\begin{tabular}{|c|c|c|c|c|}
\hline & & \multirow[t]{2}{*}{$t$-value } & \multirow[t]{2}{*}{$P$-value } \\
\hline & \multicolumn{2}{|c|}{$\begin{array}{l}\text { Table } 1 \text { Analysis of the difference in the slopes of the trendlines for admissions for } \\
\text { Kocaeli in 6-months periods before (2009) and after (2010) smoke-free legislation } \\
\begin{array}{ll}\text { Disease } & \text { Trendline equation } \\
& 2009\end{array}\end{array}$} & & \\
\hline \multirow{2}{*}{$\begin{array}{l}\text { Bronchitis } \\
\text { Lower respiratory tract infection }\end{array}$} & $10917-1017(t)$ & $5432-287(t)$ & -2.58 & $<0.05$ \\
\hline & $1360-53.0(t)$ & $659+133(t)$ & -3.94 & $<0.01$ \\
\hline \multirow{4}{*}{$\begin{array}{l}\text { Allergic rhinitis } \\
\text { Asthma } \\
\text { Chronic obstructive pulmonary disease } \\
\text { Myocardial infarction }\end{array}$} & $139+12.6(t)$ & $68.6+0.26(t)$ & 0.31 & $>0.05$ \\
\hline & $1301-47.6(t)$ & $1389-21.0(t)$ & -1.30 & $>0.05$ \\
\hline & $1791-114(t)$ & $1368-78.0(t)$ & -1.24 & $>0.05$ \\
\hline & $209-2.69(t)$ & $175+5.74(t)$ & -1.12 & $>0.05$ \\
\hline
\end{tabular}




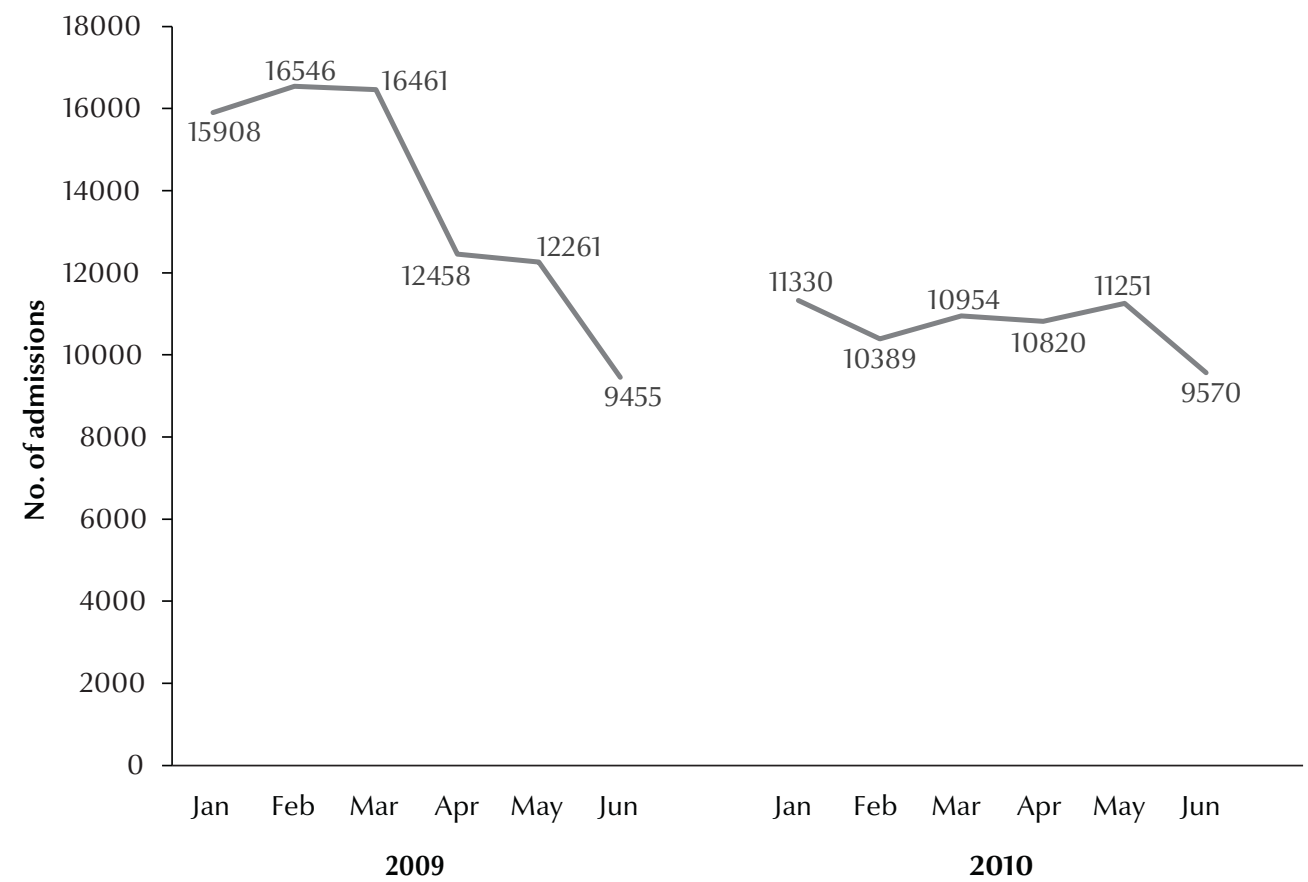

Figure 2 Monthly numbers of emergency department admissions for all smoking-related diseases in Kocaeli before and after smoke-free legislation

results the decrease in the number of admissions for allergic rhinitis was not statistically significant $(P>0.05)$. The number of emergency department admissions for asthma increased from 6805 to 7895 but the increase was not statistically significant $(P>0.05)$.

\section{Discussion}

The total number of admissions to emergency departments in Kocaeli for smoking-related diseases decreased after the implementation of smoke-free legislation in Turkey. The time-series analysis of the study showed a significant decrease in respiratory diseases such as bronchitis and LRTIs and nonsignificant reductions in the number of admissions for COPD, allergic rhinitis and myocardial infarction. In contrast, emergency admissions for asthma in-

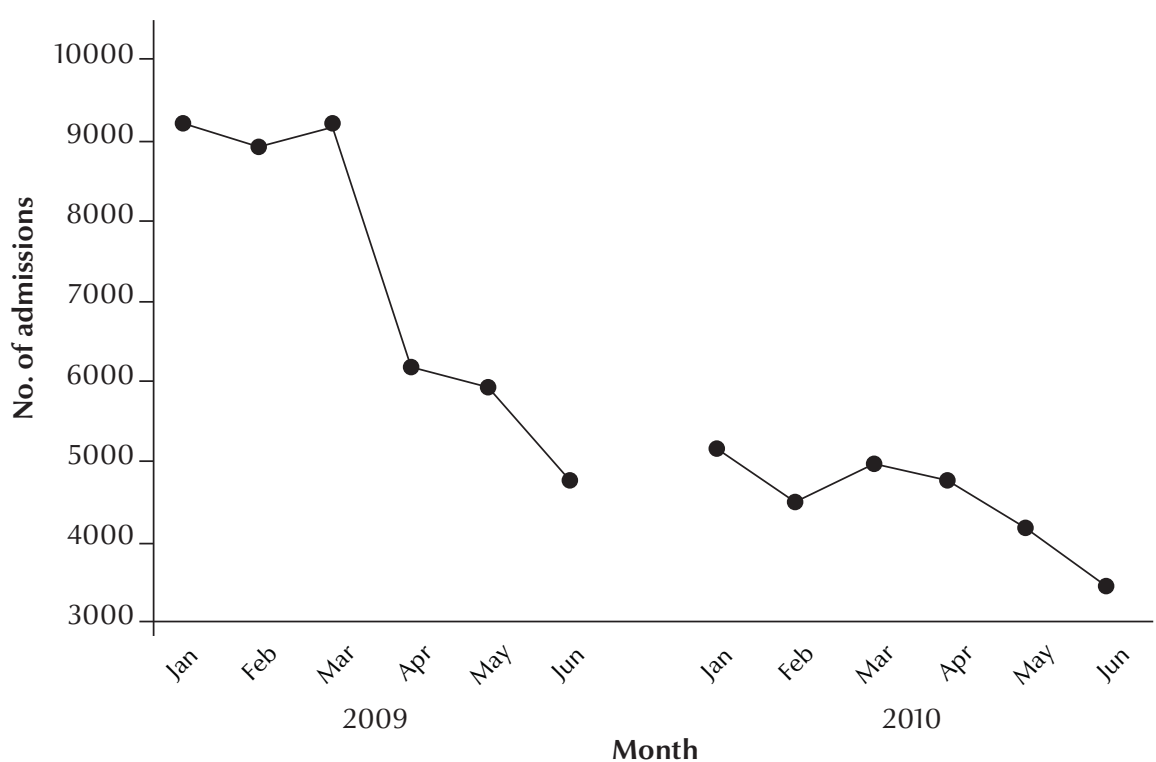

Figure 3 Slopes of the 2 trendlines for emergency department admissions for bronchitis before (2009) and after smoke-free legislation (2010) 


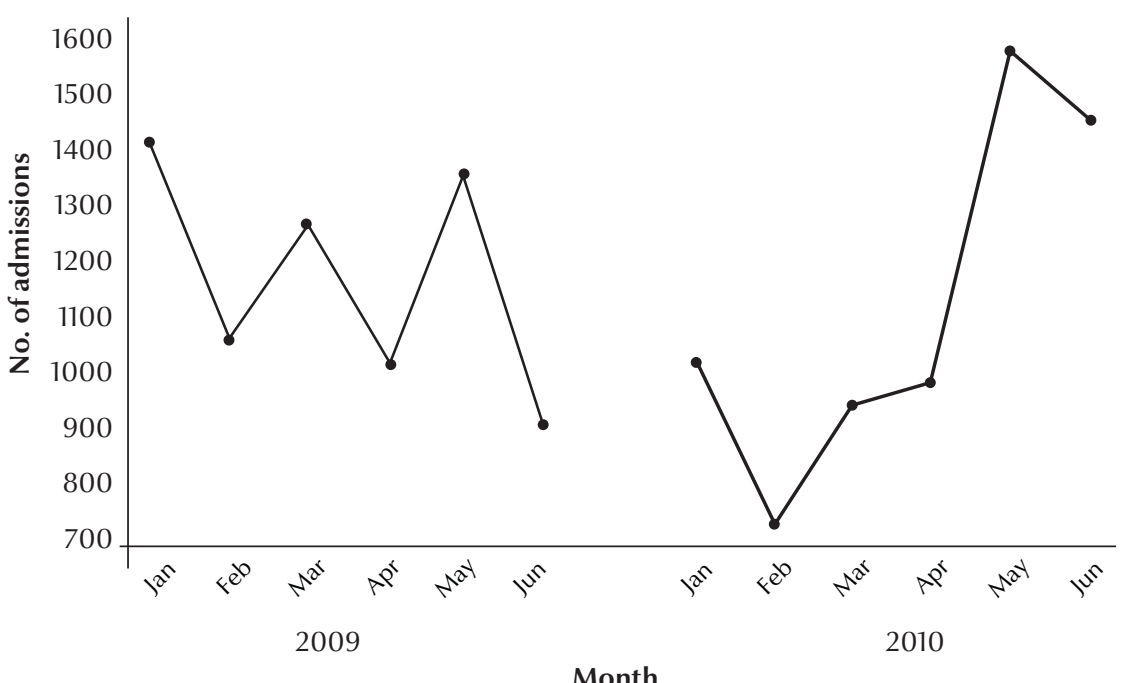

Figure 4 Slopes of the 2 trendlines for emergency department admissions for lower respiratory tract infection before (2009) and after (2010) smoke-free legislation

creased, but not significantly so, after the smoking ban.

The impact of smoke-free legislation on rates of hospital admissions for acute coronary syndromes has been investigated in various studies worldwide (712). A growing number of studies have shown evidence of reductions in admissions to hospital for acute myocardial infarction following the introduction of smoke-free legislation. Hospital admission rates for acute myocardial infarction were reduced by $8 \%$ as a result of a comprehensive smoking ban in New York State in the United States of America (7). Barone-Adesi et al. also observed a decrease in hospital admissions for acute myocardial infarction among men and women aged under 60 years in north Italy and suggested that smoke-free policies might result in a short-term reduction in admissions for acute myocardial infarction (12). It was also noted in the present study that the number of myocardial infarction cases was lower after the smoking ban but the difference was not statistically significant. It is suggested that the relatively lower number of cases diagnosed with myocardial infarction in this study might be the reason for the statistically non-significant result.

Nevertheless, to the best of our knowledge, there are few studies that have evaluated the impact of smoking legislation on respiratory outcomes (13-17). Such studies have chiefly been concerned with asthma. Second-hand tobacco smoke is a well-documented environmental trigger for the development of asthma symptoms among adults (18). Kent et al. reported that the implementation of a nationwide workplace smoking ban was associated with a decline in admissions for acute pulmonary disease among specific age groups and with an overall reduction in asthma admissions (13). Rayens et al. reported that emergency department visits for asthma declined $22 \%$ before and after introduction of the law (14). Moreover, a statistically significant reduction in hospital admissions was seen for asthma in another study (15).

On the other hand, Dove et al. were unable to find an association between smoke-free laws and self-reported current asthma. However, the smoking ban was associated with lower odds of ever having asthma with current symptoms, asthma attacks and emergency department visits for asthma, although these results were not statistically significant (16). In the presentstudy, the number of people admitted to emergency departments with asthma increased from 6805 to 7895 . Since several factors besides smoke exposure may be responsible for worsening of asthma — such as medications, exercise, air pollution, allergens and respiratory tract infections - the increased number of asthma attacks after smoking legislation suggests that other aggravating factors might affect this result. We included data from the same periods in 2 consecutive years in order to avoid seasonal variations; therefore, seasonal allergen exposure is unlikely to be responsible for the increased cases of asthma attacks. However, it is known that $\mathrm{H} 1 \mathrm{~N} 1$ virus influenza cases were prevalent between the dates of January to June 2010 in Turkey. We suggest that asthma exacerbations triggered by this viral infection may explain the increased number of cases.

Naiman et al. evaluated 3 respiratory conditions (asthma, COPD and bronchitis or pneumonia) in their study. There was a $13.5 \%$ overall reduction in hospital admissions for respiratory conditions (17). The present study found that there was a $22.5 \%$ reduction in total emergency department admissions for smoking-related diseases. This finding was virtually identical to that of Dagli et al., in a study which evaluated tobaccorelated diseases emergency department admissions in Istanbul in Turkey and reported an overall reduction rate of 


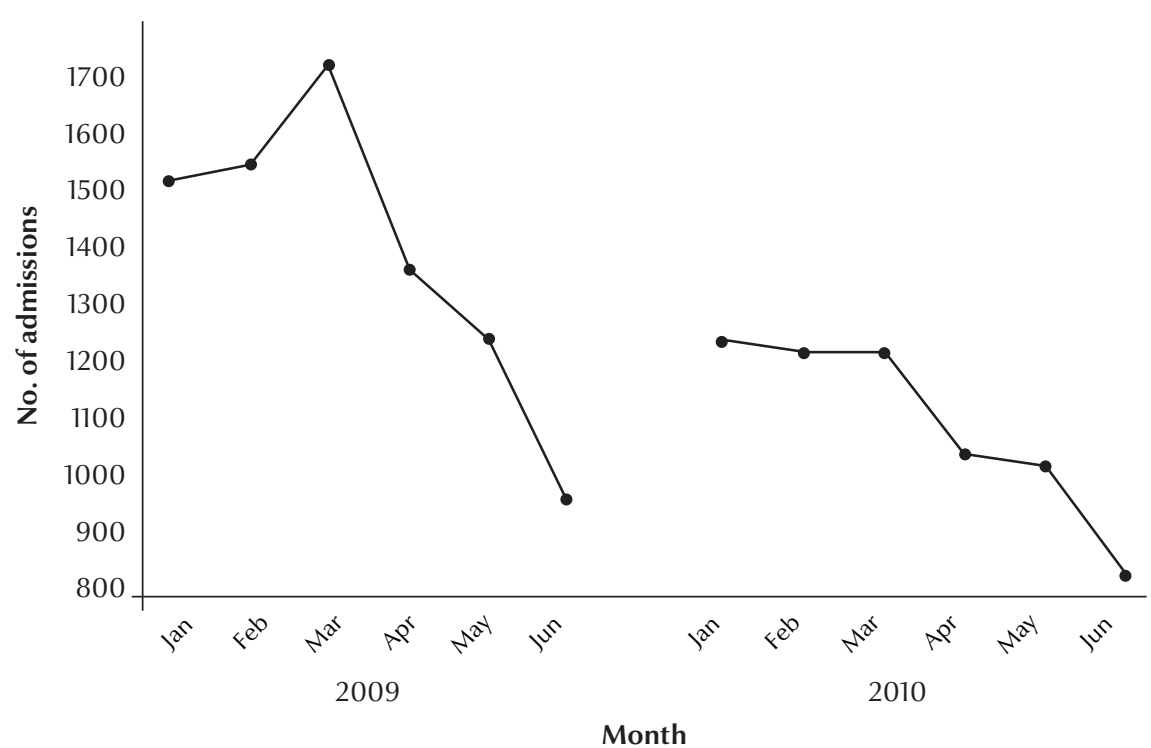

Figure 5 Slopes of the 2 trendlines for emergency department admissions for chronic obstructive pulmonary disease (COPD) before (2009) and after (2010) smoke-free legislation

$24.2 \%$ for emergency admissions for tobacco-related diseases and reductions of $21.4 \%$ and $59.2 \%$ respectively for COPD and allergic rhinitis (19). Similarly, the reduction in the total numbers of admissions for bronchitis, COPD and allergic rhinitis were $39.8 \%, 21.2 \%$ and $61.9 \%$ respectively in our study. However, time-series analysis showed that the decreases were statistically significant only for cases of bronchitis and LRTI. This might be related to the relatively lower number of cases of COPD and allergic rhinitis in the study compared with bronchitis and LRTIs. Although it was not statistically significant, there was a trend of decrease in both COPD and allergic rhinitis admissions after the smoking ban. Furthermore, time-trend slopes of COPD and allergic rhinitis had significant peaks, which were interpreted as increased numbers of admissions in certain months, while these peaks were not observed in the time-trend slopes after the smoking ban.

Some limitations of the study can be noted. We believe that other factors such as implementation of family-medicinebased primary care in Turkey, decline in smoking prevalence, reductions in daily cigarette consumption among smokers and an increased public health focus on smoking cessation may also have affected rates of admission to hospital by reducing smoking behaviour and episodes of smoking-related diseases. However, these confounding factors are also related to the smoking legislation and together these data emphasize the importance of the implementation of smoke-free laws. Since no data were collected before 2009, and this study did not include the total numbers of emergency admissions other than smoking-induced diseases, we could not clearly interpret the trend in emergency admissions.

The data about the emergency department admissions were received from the Directorate of Health in Kocaeli. Since our data did not include demographic characteristics, we could not discuss the results according to age and sex and smoking habits. Although the primary aim of smoking bans is to decrease exposure to second-hand smoke for non-smokers, such bans may also have an impact on active smoking. The weakness of this study was the inability to assess the effect of altered smoking prevalence on hospital admissions given the causal relation between active smoking and tobacco-related disease.

\section{Conclusions}

The number of admissions to emergency departments for smoking-related respiratory diseases and myocardial infarction decreased after the implementation of smoke-free legislation. The strength of association of smoke-free legislation with certain tobacco-related diseases may be weak; however, since there was an overall reduction in emergency admissions for respiratory diseases, we suggest that the smoking ban may be linked to the significant decline in hospital admissions for respiratory diseases in the short-term. The long-term effects of smoke-free legislation on tobaccorelated diseases and smoking prevalence should be evaluated in future long-term prospective studies in order to emphasize the importance of smoke-free environment and to motivate the authorities to implement stronger smoke-free laws.

\section{Acknowledgements}

Data were collected with the support of the Directorate of Health in Kocaeli.

Funding: No outside funding.

Competing interests: None declared. 


\section{References}

1. Koh HK, Joossens LX, Connolly GN. Making smoking history worldwide. N Engl J Med. 2007 Apr 12;356(15):1496-8. PMID:17429081

2. Nelson E. The miseries of passive smoking. Hum Exp Toxicol. 2001 Feb;20(2):61-83. PMID:11327513

3. Jaakkola MS, Jaakkola JJ. Effects of environmental tobacco smoke on the respiratory health of adults. Scand J Work Environ Health. 2002;28 Suppl 2:52-70. PMID:12058803

4. Radon K, Büsching K, Heinrich J, Wichmann HE, Jörres RA, Magnussen $\mathrm{H}$, et al. Passive smoking exposure: a risk factor for chronic bronchitis and asthma in adults? Chest. 2002 Sep;122(3):1086-90. PMID:12226059

5. Larsson ML, Loit HM, Meren M, Põlluste J, Magnusson A, Larsson $\mathrm{K}$, et al. Passive smoking and respiratory symptoms in the FinEsS Study. Eur Respir J. 2003 Apr;21(4):672-6. PMID:12762355

6. Jordan RE, Cheng KK, Miller MR, Adab P. Passive smoking and chronic obstructive pulmonary disease: cross-sectional analysis of data from the Health Survey for England. BMJ Open. 2011 Jan 1;1(2):e000153. 10.1136/bmjopen-2011-000153 PMID:22021874

7. Juster HR, Loomis BR, Hinman TM, Farrelly MC, Hyland A, Bauer UE, et al. Declines in hospital admissions for acute myocardial infarction in New York state after implementation of a comprehensive smoking ban. Am J Public Health. 2007 Nov;97(11):2035-9. PMID:17901438

8. Lightwood JM, Glantz SA. Declines in acute myocardial infarction after smoke-free laws and individual risk attributable to secondhand smoke. Circulation. 2009 Oct 6;120(14):1373-9. PMID:19770392

9. Gasparrini A, Gorini G, Barchielli A. On the relationship between smoking bans and incidence of acute myocardial infarction. Eur J Epidemiol. 2009;24(10):597-602. PMID:19649714

10. Meyers DG, Neuberger JS, He J. Cardiovascular effect of bans on smoking in public places: a systematic review and meta-analysis. J Am Coll Cardiol. 2009 Sep 29;54(14):1249-55. PMID:19778665

11. Pell JP, Haw S, Cobbe S, Newby DE, Pell AC, Fischbacher C, et al. Smoke-free legislation and hospitalizations for acute coronary syndrome. N Engl J Med. 2008 Jul 31;359(5):482-91. PMID:18669427
12. Barone-Adesi F, Vizzini L, Merletti F, Richiardi L. Short-term effects of Italian smoking regulation on rates of hospital admission for acute myocardial infarction. Eur Heart J. 2006 Oct;27(20):2468-72. PMID:16940340

13. Kent BD, Sulaiman I, Nicholson TT, Lane SJ, Moloney ED. Acute pulmonary admissions following implementation of a national workplace smoking ban. Chest. 2012 Sep;142(3):6739. PMID:22383660

14. Rayens MK, Burkhart PV, Zhang M, Lee S, Moser DK, Mannino $\mathrm{D}$, et al. Reduction in asthma-related emergency department visits after implementation of a smoke-free law. J Allergy Clin Immunol. 2008 Sep;122(3):537-41, e3. PMID:18692884

15. Herman PM, Walsh ME. Hospital admissions for acute myocardial infarction, angina, stroke, and asthma after implementation of Arizona's comprehensive statewide smoking ban. Am J Public Health. 2011 Mar;101(3):491-6. PMID:20466955

16. Dove MS, Dockery DW, Connolly GN. Smoke-free air laws and asthma prevalence, symptoms, and severity among nonsmoking youth. Pediatrics. 2011 Jan;127(1):102-9. PMID:21149426

17. Naiman A, Glazier RH, Moineddin R. Association of antismoking legislation with rates of hospital admission for cardiovascular and respiratory conditions. CMAJ. 2010 May 18;182(8):761-7. PMID:20385737

18. Eisner MD, Klein J, Hammond SK, Koren G, Lactao G, Iribarren C. Directly measured second hand smoke exposure and asthma health outcomes. Thorax. 2005 Oct;60(10):814-21. PMID:16192366

19. Dağı E, Erdem E, Birinci Ş, Topçu İ, Dokucu Ai, Ersu R, et al. İstanbul'da sigara yasağının uygulanmasının tütün kullanımı ve pasif içicilikle ilgili tanılarda acil servis başvuruları üzerine etkisinin değerlendirilmesi. [The impact of smoking ban on emergency department admissions in Istanbul for the diseases associated with tobacco usage and passive smoking.] Paper presented at the 14th Annual Congress of the Turkish Thoracic Society, 13-17 April 2011. Antalya, Turkey: Turkish Thoracic Society; 2011 (http://www.abstractagent.com/av2/afpr.asp?p dir=2011toraks\&plng=eng\&au=0633\&afu=83556, accessed 25 September 2014). 